\title{
IDENTIFICATION OF SOME TREMATODE CERCARIAE COLLECTED FROM SIX MARINE SNAIL SPECIES OF THE GENUS NERITA.
}

\section{By}

AMAAL HASSAN ${ }^{1,2 *}$, MUSLIMAH AL-SOLAMI ${ }^{1}$ and SABAH M. HASSAN ${ }^{1,3}$ Department of Biology ${ }^{1}$, Science College, King Abdulaziz University, Jeddah, Saudi Arabia.Department of Zoology ${ }^{2}$, Faculty of Science, Sohag University, Sohag, Egypt and Department of Genetics ${ }^{3}$, Faculty of Agriculture, Ain Shams University, Cairo, Egypt ( ${ }^{*}$ Correspondence: ahassanmo@gmail.com, phone: +966502679429).

\section{Abstract}

Transmission of trematode cercariae depends mainly on the presence of marine snails as an intermediate host for zoonotic diseases. Parasitic infections in marine snails are poorly discussed. The current study was aimed to investigate the collected snails and determine the prevalence of larval trematode infections as well as identifying the cercarial types from January to December 2016. A total of 549 marine snails belonging to the genus, Nerita were randomly collected from Obhor bay, Red Sea at Jeddah city, Saudi Arabia. To harvest cercariae, snails were exposed to artificial light and the non-shedding snails were crushed. Eight distinct cercariae were identified as well as their sporocysts. Seven of them were found belonging to non-virgulate xiphidiocercaria: Ascorhytis charadriformis, cercariae, Haematoloechus similis, Litorina saxatilis V, Litorina saxatilis VII, Maritrema lingulla, Microphallus similis, Microphalliae and one ocellate furcocercous. The most prevalent type of cercariae was Maritrema lingulla (16.96\%). The described cercariae are part of a diverse group of about eight trematode species inhabiting marine Nerita snails as first intermediate hosts. Such studies can assist in collecting data on disease distribution in the sympatric fish and the configuration of trematodes transmission by snails and eventually, in the avoidance and control of the subsequent fish and human diseases.

Key words: Marine snails, Nerita, Sporocyst, Cercariae, Trematoda, Red Sea

\section{Introduction}

Most snails are intermediate hosts for trematode cercariae infecting humans and animals. The life cycle of trematodes is very complex, as they require an intermediate snail or fish for the maturation to the infective stage. Cercariae are adapted for dispersal outside snail and exhibit a large variety in morphology to penetrate the second intermediate host (Graczyk and Fried, 1999).

Trematode groups often consist of different species inhabiting the same host population, with two or more trematodes sometimes sharing the same host (Born-Torrijos et al, 2014). The detection of infection in snails depends on; stimulation of cercarial shedding by exposing snails to light, crushing of snails, followed by microscopic examination and finally rearing of snails in the laboratory occurs until they shed cercariae (Hanelt et al, 1997).

Taxonomic position of numerous trematode cercariae often cannot be established based on their morphology alone due to the shortage of consistent taxonomic distinguishing features at this stage of trematodes development. Cercariae can be identified to the family or superfamily level. Laboratory experiments on life cycles using natural definitive hosts are not always possible (Bartoli et al, 2000; Brant et al, 2006; Pina et al, 2007; Jensen and Bullard, 2010; Locke et al, 2011). Little studies were carried out on diversity and abundance of cercariae in the Red Sea snails. Such studies gave data on environmental factors influencing emergence of cercariae in marine system (Koprivinikar and Poulin, 2009).

The current study was aimed to investigate the collected marine snails, Nerita spp., to determine prevalence of larval trematode infections and to identifythe cercariae infecting them.

\section{Materials and methods}

Snails were gathered from Obhor Bay located about $30 \mathrm{~km}$ north of Jeddah City on 
east coast of the Red Sea, and were transferred to the Parasitology laboratory, Science college, King Abdulaziz University. Collection was carried out from January to December 2016. Snails were identified using standers keys (Knaap and Loker, 1990; Rusmore-Villaume, 2008). They belong to genus Nerita, comprises six species; Nerita albicilla, $N$. grayana, $N$. histrio, $N$. polita, $N$. orbignyana and $N$. quadricolor.

Shedding and harvesting of cercariae: Snails were cleaned, individually separated in small glass beakers containing seawater and were kept in the laboratory at $23^{\circ} \mathrm{C}$. They were exposed to artificial light for two hours. Under a dissecting microscope, water drops from each beaker was investigated at short intervals searching for emerging cercariae. Non-shedding snails were crushed and investigated using the dissecting microscope searching for early larval trematode stages. Living cercariae were stained with diluted vital stain methylene blue. The stained cercariae were characterized and photographed. Cercariae were identified according to their morphological features using taxonomic keys (Hassan et al, 2017).

\section{Results}

Eight distinguishable types of cercariae were collected from Nerita spp, seven of them were found belonging to xiphidiocercaria and one ocellate furcocercus. Infection prevalence for each cercarial type was recorded; cercaria of Ascorhytis charadriformis found $1.7 \%$, Cercaria of Haematoloechus similis in $5.94 \%$, cercaria of Litorina saxatilis $\mathrm{V}$ in $11.87 \%$, cercaria of Litorina saxatilis VII in $7.64 \%$, cercaria of Maritrema lingulla in $16.96 \%$, cercaria of Microphallus similis in $3.40 \%$ and cercaria of Microphalliae in $16.96 \%$ and ocellate furcocercous cercaria in $1.7 \%$. All cercariae developed in sporocysts. Measurements were given (Tab. 1). Cercaria of Ascorhytis charadriformis (Young, 1949) Ching, 1965: Cercaria was found in snail, Nerita orignyana and N. histrio. Body is oval to elongate, creamy color. Tail is simple and longer than body. Oral sucker is terminal, rounded in shape without virgula organ. A well-deve-loped stylet arises from oral sucker with an arrow like terminal end with sharp tip and broad base. Ventral sucker not detected. Pharynx detected and digestive system remainder could be detected. Four pairs of penetration glands on ventral sucker sides. An excretory bladder is circular found in body posterior end (Fig. 1A, B).

Cercaiae of Haematoloechus similis: Cercaria was found in snail, Nerita orbignyana and $N$. histrio. Body is oval, creamy color. Tail is simple and shorter than body. Oral sucker is terminal, rounded freed from virgula organ. A well-developed stylet arises from oral sucker with an arrow like terminal end. Ventral sucker is rounded with six pairs of penetration glands on either side. Excretory bladder is $\mathrm{Y}$ shape in body posterior end (Fig. 1, C, D).

Cercaria of littorina saxatilis V Popiel, 1976: Cercaria was found in snail, Nerita albicilla and $N$. grayana. Body is oval, creamy color. Tail is simple and shorter than body. Oral sucker is sub terminal, rounded in shape without virgula organ. A welldeveloped stylet arises from oral sucker with an arrow like terminal end and broad base. Ventral sucker not detected. Esophagus bifurcates into ventral sucker anterior part. Two pairs of penetration glan-ds on ventral sucker each side. Excretory bladder not identified (Fig. 2A, B).

Cercaria of Litorina saxatilis VII Cercaria Newell, 1986: Cercaria was found in snail, Nerita grayana. Body is elongate, creamy color. Tail is simple and nearly same as body length. Oral sucker is terminal, rounded in shape without virgule organ. A welldeveloped stylet arises from the oral sucker and has an arrow like terminal end with sharp tip with broad base. Four pairs of penetration glands, two lying on either sides of oral sucker, and two at genital premordium level, open on each side of stylet tip. Excretory bladder is irregular in shape in body posterior end. Genital primordium found in 
between excretory bladder and posterior penetration glands (Fig. 2C, D).

Cercaria of Maritrema linguilla Jagerskiold, 1908: Cercaria was found in Nerita albicilla, $N$. quadricolor and $N$. orbignyana. Body is transparent and elongate in shape. Tail is simple and shorter than body. Oral sucker is subterminal, rounded in shape without virgula organ. A well-developed stylet arises from oral sucker with an arrow like terminal end with sharp tip. Ventral sucker undetected. Four pairs of penetration glands on each side of ventral sucker. Excretory bladder is circular in shape, found in body posterior end (Fig. 3A, B).

Cercaria of Microphallus similis Jagerskiold, 1900: Cercaria was found in snail, Nerita orbignyana. Body is oval to elongate with creamy color. Tail is simple and longer than body. Oral sucker is subterminal, rounded in shape freed from virgula organ. A well-developed stylet arises from oral sucker with an arrow like terminal end and broad base. Ventral sucker is absent. Four pairs of penetration glands. Excretory bladder is circular in shape found in body posterior end (Fig. 3C, D).

Cercaria of Microphallidae spp. Travassos, snail, Nerita histrio. Body is oval to elongate in shape and creamy in color. Tail is simple and smaller than body. Oral sucker is sub terminal, rounded in shape free from virgula organ. A well-developed stylet arises from oral sucker with an arrow like terminal end and broad base. Digestive system is not developed. Penetration glands arranged in two pairs, located in third quarter of body. Posterior pairs of penetration glands not observed. Ducts open ventrolaterally to stylet. Genital primordium forms an oval mass in body posterior third. Excretory bladder is $\mathrm{Y}$ shaped (Fig. 4A, B).

Ocellate furcocercous cercaria Faust, 1918: This cercaria was collected from snail, Nerita polita. Body is long, flat-like and oval shaped, creamy in color. Tail is longer than body and divided into two furcae measuring about $45 \mu \mathrm{m}$ in length. Pharynx is quite small with two pairs of large penetration glands. Two eyespots are globularly shaped located in anterior position near pharynx. Penetration glands two pairs in body third quarter. Posterior pairs of penetration glands not observed. Genital primordium is an oval mass in body posterior third. Excretory bladder is Y-shaped (Fig. 4C, D).

1920: These cercariae were obtained from

\begin{tabular}{|l|c|c|c|c|c|c|c|}
\hline Type of cerceriae & Body & Tail & Oral sucker & Stylet & Ventral sucker & Excretory bladder & Sporocyst \\
\hline Ascorhytis charadriformis & $25 \times 66.67$ & 58.33 & 12.5 & 5.83 & absent & 15 \\
\hline Haematoloechus similis & $18.50 \times 18.33$ & 15 & 8.33 & 10.83 & 4.16 & $37.5 \times 75$ \\
\hline Iitorina saxatilis V & $12.5 \times 50.17$ & 21.67 & 8.3 & 4.17 & absent & Unidentified & $23.33 \times 75$ \\
\hline Iitorina saxatilis VII & $54.17 \times 12.5$ & 29.17 & 12 & 6.67 & absent & 13 & $91.6 \times 50$ \\
\hline Maritrema linguilla & $50 \times 16.67$ & 29.17 & 8.33 & 10 & absent & 9 & $45.83 \times 20$ \\
\hline Microphallus similis & $33.33 \times 12.5$ & 40.5 & 8.33 & 4.17 & absent & 7 & $65 \times 17.5$ \\
\hline Microphallidae spp & $47.5 \times 19.17$ & 29.17 & 12.5 & 4.17 & absent & 10 & $70.83 \times 20$ \\
\hline Ocellate furcocercous & $20.83 \times 0.42$ & 45 & absent & absent & absent & absent & $100 \times 18.33$ \\
\hline
\end{tabular}

Table 1: Measurements of cercariae collected from Nerita snails (All measurements in $\mu \mathrm{m}$ )

\section{Discussion}

In the present work, eight types of cercariae were identified from Nerita spp, seven of which belong to non-virgulate xiphidiocercaria; Ascorhytis charadriformis, cercariae, Haematoloechus similis, Litorina saxatilis V, Litorina saxatilis VII, Maritrema lingulla, Microphallus similis, Micro-phalliae and one ocellate furcocercous cercaria.

Ascorhytis charadriformis was collected from the brackish water snail, Littorinopsis intermedia in the central and east coast of the gulf in Thailand by Namchote et al. (2015). They found the adult in large intestine of dunlin, Calidris alpina and was originally described from charadriiform birds in California (Young, 1949). Gulls are other avian hosts in the life cycle which involves littorine snails and grapsid crab intermediate hosts (Cheng, 1963). The present record of Ascorhytis charadriformis cercaria in the marine snails, Nerita orignyana and N. histrio is the first in Saudi Arabia.

In the present work, $H$. similis cercariae 
were collected from marine snails, Nerita orbignyana and Nerita histrio. This cercaria was reported only from planorbid snails in central Europe by Faltynkova et al. (2007). The life cycle of Haematoloechus similis was traced experimentally. The first intermediate host was Planorbis planorbis. The metacercariae are found in the larvae of several species of Insecta. Adult flukes were obtained from Rana esculenta. The cercariae of $H$. similis resemble those of the group "Prima" of the "Cercariae ornatae" in size and body proportions but also resemble those of the "Cercariae armatae" group in the nature of the excretory system and in the absence of a caudal finfold; the cercariae of $H$. similis differ from those of both groups by possessing prominent penetration glands and by the absence of cystogenous glands (Grabda et al, 1960).

Irwin et al. (1983) recorded that littorinae saxatilis $\mathrm{V}$ had been previously described by Popiel (1976) on the eastern Atlantic seaboard. Irwin et al., 1990 pointed in his study that cercariae of M.arenaria are the previously known as cercaria Iittorinae saxatilis $\mathrm{V}$. The current study recorded $l$. saxatilis $\mathrm{V}$ from snails, Nerita albicilla and Nerita grayana for the first time in Saudi Arabia.

littorina saxatilis VII cercariae were originally described by Newell (1986), these samples were collected from Littorina saxatilis snails in the Scilly Isles. The morphology and morphometry discussed by Newell (1986) agreed with that recorded in Iceland. Evidences from the previous work suggest that Onoba aculeus is the main first intermediate host for littorina saxatilis VII cercariae. littorina saxatilis VII cercariae entered and encysted in the isopod, Jaera albifrons (Leach) which mean that waders inhabiting the intertidal coast may represent the final hosts for this cercaria. In the present study, these cercariae were recorded from the marine snails, Nerita grayana for the first time.

Cercariae of Maritrema linguilla were collected from marine snails, Nerita albicilla, $N$. quadricolor and $N$. orbignyana in the present study. Newell (1986) documented M. linguilla infection from $L$. saxatilis in the studied coastal regions. M. linguilla cercariae were recorded also from $L$. saxatilis snails found on French coast (Richard, 1976), this can clarified by the specific environmental conditions in the island as intertidal zone. $M$. linguilla was not detected in Littorina spp. in Barents Sea coast or the Norwegian Sea (Chubrik, 1966; Podlipaev, 1979; Galaktionov and Bustnes, 1999). Adult cercariae of $M$. murmanica were defined by (Deblock and Capron, 1960; Newell, 1986; Benjamin and James, 1987). The second intermediate host for M. linguilla is the, Ligia oceanica (L.) host belonging to Crustacea. The present record of this cercaria is the first in Saudi Arabia.

Stunkard (1957) recoded the life-history of Microphallus similis by experimental infection of both intermediate and final hosts. The cercariae are minute, stylet-bearing monostomes. Microphallus species are mainly intestinal parasites of birds and mammals, and its metacercariae have been revealed in the crab (Guk et al., 2008). Microphallus similis invests numerous hosts to complete its life cycle, starting with two Littorina snails ( $L$. saxatilis and L. obtusata), where the trematode reproduces asexually to give many cercariae. These cercariae leave the snail into water searching for the secondintermediate host, the green crab, Carcinus maenas, to encyst within it to metacercariae. The crab host must be eaten by a definitive host, often a Larus gull species, where the trematode reproduces sexually, and their eggs are then deposited into the surrounding marine environment within the feces of the birds.

Kudlai et al. (2016) described the life cycles of Microphallids. They involve gastropods, mostly marine and brackish water, as first intermediate hosts and crustaceans as second intermediate hosts. Martorelli et al. (2006) found cercaria in Zeacumantus subcarinatus in New Zealand that agreed with Microphallid cercariae. Also, two pairs of 
anterior cephalic glands behind oral sucker llus Travassos 1920 and Megalophallus Cable, Connor \& Balling, 1960 and in accordance with Microphallid cercarial type in the present study. Galaktionov et al. (2012) reported that Microphallus species' life cycle has two hosts; metacercariae develop (intertidal and subtidal gastropods, mostly of genus Littorina) and infective to marine birds (ducks, gulls and waders). Faltynkova et al. (2007) reported eight species of furcocercous cercariae of families (Strigeidae, Diplostomidae, Schistosomati dae and Sanguinicolidae), from Lake Konnevesi in Finland in (Valvata macrostoma, Lymnaea stagnalis, Bathyomphalus contortus and Planorbarius corneus). Snail hosts of furcocercous cercaria were $B$. siamensis, $F$. polygramma and $M$. tuberculata. Chontananarth and Chai (2013) in Thailand collected this cercaria from M. tuerculata and Tarebia scabra. In the current study, this cercaria from Nerita polita, which life cycle must be studied?

\section{Conclusion}

The described cercariae are part of a diverse group of about eight trematode species inhabiting marine Nerita snails. Such studies can assist in collecting data on disease distribution in the sympatric fish and the configuration of trematodes transmission by snails and eventually, in avoidance and control of subsequent fish and human diseases.

\section{References}

Born-Torrijos, A, Poulin, R, Raga, JA, Holzer, AS, 2014: Estimating trematode prevalence in snail hosts using a single-step duplex PCR: how badly does cercarial shedding underestimate infection rates?. Parasit. Vectors 7:243-254.

Bartoli, P, Jousson, O, Russell-Pinto, F, 2000: The life cycle of Monorchis parvus (Digenea: Monorchiidae) demonstrated by developmental and molecular data. J. Parasitol. 86:479-89.

Benjamin, LR, James, BL, 1987: The development of the metacercariae of Maritrema linguilla Jäg., 1908 (Digenea: Microphallidae) in the intertidal host, Ligia oceanica (L.). Parasitol. 94:221-31.

Brant, SV, Morgan, JA, Mkoji, GM, Snyder, SD, Rajapakse, RPVJ, et al, 2006: An approach to revealing blood fluke life cycles, tax- posterior margin characteristic of Microphaonomy, and diversity: provision of key reference data including DNA sequence from single life cycle stages. J. Parasitol. 92: 77-88.

Ching, HL, 1963: The life cycle and bionomics of Levinseniella charadriformis Young, 1949 (Trematoda: Microphallidae). Cana. J. Zool. 41: 889-899.

Chontananarth, T, Wongsawad, C, 2013: Epidemiology of cercarial stage of trematodes in freshwater snails from Chiang Mai province, Thailand. Asian Pac. J. Trop. Bio med. 3:237-43.

Chubrik, GK, 1966: Fauna and ecology of trematode larvae from molluscs in the Barents and White Seas. Trudy Murmansk. Morsk. Biol. Inst. 10:78-166.

Deblock S, Capron A, Rose, F, 1961: Contribution à l'étude des Microphallidae Travassos, 1920 (Trematoda). V. Le genre Maritrema Nicoll, 1907: cicle évolutif de M. subdolum Jëgerskioeld, 1909. Parasitologia 3:105-19.

Faltynkova, A, Nasincova, V, Kablaskova, L, 2007: Larval trematodes (Digenea) of the great pond snail, Lymnaea stagnalis (L.), (Gastropoda, Pulmonata) in Central Europe: a survey of species and key to their identification. Parasite 14: 39-51.

Faltynkova, A, Niewiadomska, K, Santos, M, Valtonen, E, 2007: Furcocercous cercariae (Trematoda) from freshwater snails in Central Finland. Acta Parasitol. 52:310-7.

Galaktionov, KV, Bustnes, JO, 1999: Distribution patterns of marine bird digenean larvae in periwinkles along the southern coast of the Barents Sea. Dis. Aquat. Organisms 37:221-30.

Galaktionov, KV, Blasco-Costa, I, Olson, P, 2012: Life cycles, molecular phylogeny and historical biogeography of the 'pygmaeus'microphallids (Digenea: Microphallidae): widespread parasites of marine and coastal birds in the Holarctic. Parasitology 139: 1346-60.

Grabda, B, 1960: Life cycle of Haematoloechus similis (Looss, 1899) (Trematoda-Plagiorchiidae). Acta Parasitol. Pol. 8:357-67.

Graczyk, TK, Fried, BE, 1999: Development of Fasciola hepatica in the intermediate host. In: Fasciolosis. CABI, UK.

Guk, SM, Chai, JY, Sohn, WM, Kim, Y M, Sim, S, Seo, M, 2008: Microphallus koreana n. sp.(Trematoda: Microphallidae) transmitted by a marine crab, Macrophthalmus dilatatus. Korea. J. Parasitol. 46:165-9.

Hanelt, B, Adema, CM, Mansour, MH, Lok- 
er, ES, 1997: Detection of Schistosoma mansoni in Biomphalaria using nested PCR. J. Parasitol. 83:387-94.

Hassan, A, Al-solami, M, Hassan, SM, 2017: Prevalence of trematode larval infections in some Red Sea snails. Aust. J. Bas. Appl. Sci. 11: 69-7.

Irwin, SWB, 1983: Incidence of trematode parasites in two populations of Littorina saxatilis (Olivi) from the north shore of Belfast Lough. Irish Naturalists J. 21:26-9.

Irwin, SWB, Maguire, JG, Saville, DH, 1990: Identification of the cercarial stage of Maritrema arenaria (syn. M. gratiosum) (Trematoda: Microphallidae). J. Nat. Hist. 24:949-54.

Jensen, K, Bullard, SA, 2010: Characterization of a diversity of tetraphyllidean and rhinebothriidean cestode larval types, with comments on host associations and life-cycles. Int. J. Parasitol. 40:889-910.

Knaap, WVD, Loker, ES, 1990: Immune mechanism in trematode-snail interaction. Parasitol. today 6:175-82.

Koprivnikar, J, Poulin, R, 2009: Effects of temperature, salinity, and water level on the emergence of marine cercariae. Parasitol. Res. 105: 957-65.

Kudlai, O, Cribb, TH, Cutmore, SC, 2016: A new species of microphallid (Trematoda: Digenea) infecting a novel host family, the Muraenidae, on the northern Great Barrier Reef, Australia. Syst. Parasitol. 93: 863-76.

Locke, SA, McLaughlin, JD, Lapierre, A R, Johnson, PT, Marcogliese, DJ, 2011: Linking larvae and adults of Apharyngostrigea cornu,
Hysteromorpha triloba, and Alaria mustelae (Diplostomoidea: Digenea) using molecular data. J. Parasitol. 97:846-51.

Martorelli, SR, Poulin, R, Mouritsen, KN, 2006: A new cercaria and metacercaria of Acanthoparyphium (Echinostomatidae) found in an intertidal snail Zeacumantus subcarinatus (Batillaridae) from New Zealand. Parasitol. Inter. 55: 163-7.

Namchote, S, Sritongtae, S, Butnin, S, Wongwain, P, Krailas, D, 2015: Larval stage of trematodes obtained from brackish water snails in the central and east coast of the gulf of Thailand. Sci. Res. Essay 10:386-401.

Newell, CR, 1986: The marine fauna and flora of the Isles of Scilly: some marine digeneans from invertebrate hosts. J. Nat. Hist. 20:71-7.

Pina, SM, Russell-Pinto, F, Rodrigues, P, 2007: Clarification of Cercaria sevillana (Digenea: Microphallidae) life cycle using morphological and molecular data. J. Parasitol. 93:318-22.

Podlipaev, SA, 1979: Trematode parthenitae and larvae in the intertidal molluscs of the Eastern Murman. Ecol. Exp. Parasitol. 2:47-101.

Richard, J, 1976: Etude comparee de la repartition des cils chez quelques especes de Microphallidae Travassos, 1920. Zeitschr. Parasitenk. 43: 71:88.

Rusmore-Villaume, ML, 2008: Seashells of the Egyptian Red Sea: Illustrated Handbook. American University in Cairo Press.

Stunkard, HW, 1957: The morphology and life-history of the digenetic trematode, Microphallus similis (Jagerskiold, 1900) Baer, 1943. Biol. Bull. 112: 254-66.

\section{Explanation of figures}

Fig.1: Photomicrograph showing A, B. Ascorhytis charadriformis A, sprocyst and B, cercaria, C, D: Haematoloechus similis C, sporocyst and D, cercaia. (EB) excretory bladder, (OS) oral sucker, (PG) penetration glands, (S) stylet, (TA) small tail

Fig. 2: Photomicrograph showing A, B. litorina saxatilis V, A, sprocyst and B, cercaria; C, D: litorina saxatilis VII, C, sporocyst and D, cercaia. (EB) excretory bladder, (OS) oral sucker, (PG) penetration glands, (S) stylet, (TA) small tail.

Fig. 3: Photomicrograph showing A, B. Maritrema linguilla. A, sprocyst and B, cercaria, C, D: Microphallus similis. C, sporocyst and D, cercaia. (EB) excretory bladder, (OS) oral sucker, (PG) penetration glands, (S) stylet, (TA) small tail.

Fig. 4: Photomicrograph showing A, B Microphallidae. A, sprocyst and B, cercaria. C, D: Ocellate furcocercus. C, sporocyst and D, cercaia. (EB) excretory bladder, (OS) oral sucker, (PG) penetration glands, (S) stylet, (TA) small tail. 

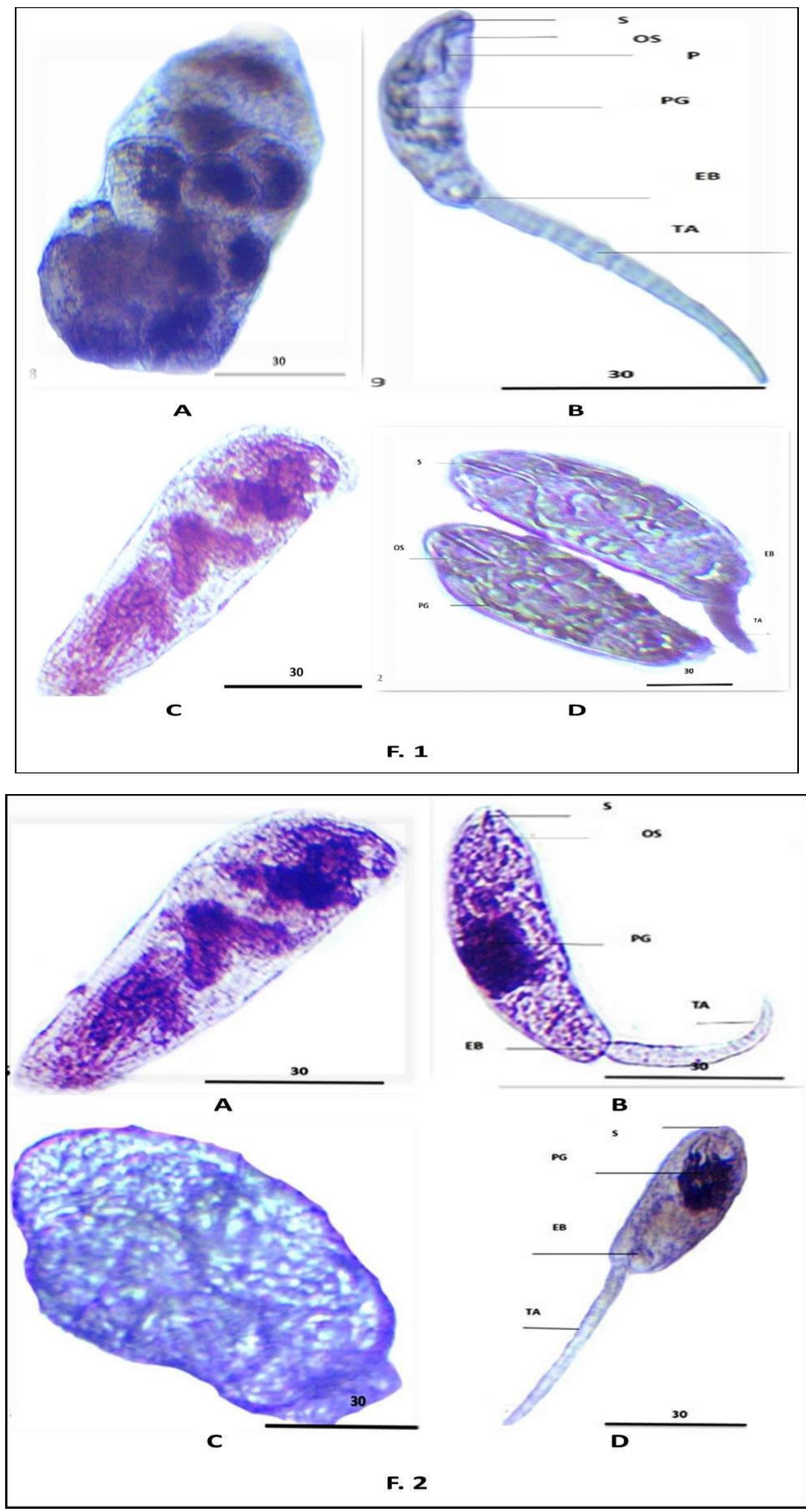

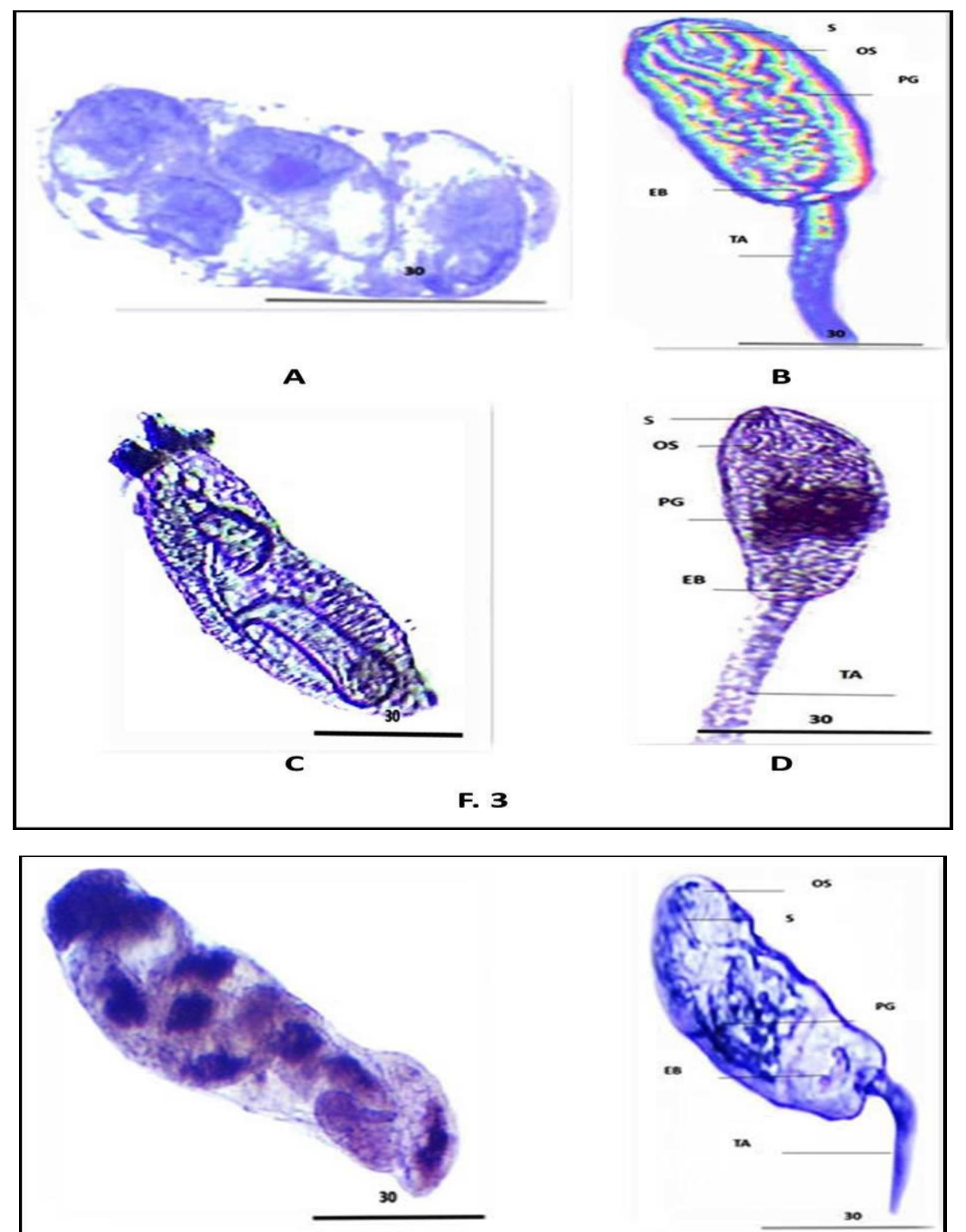

A
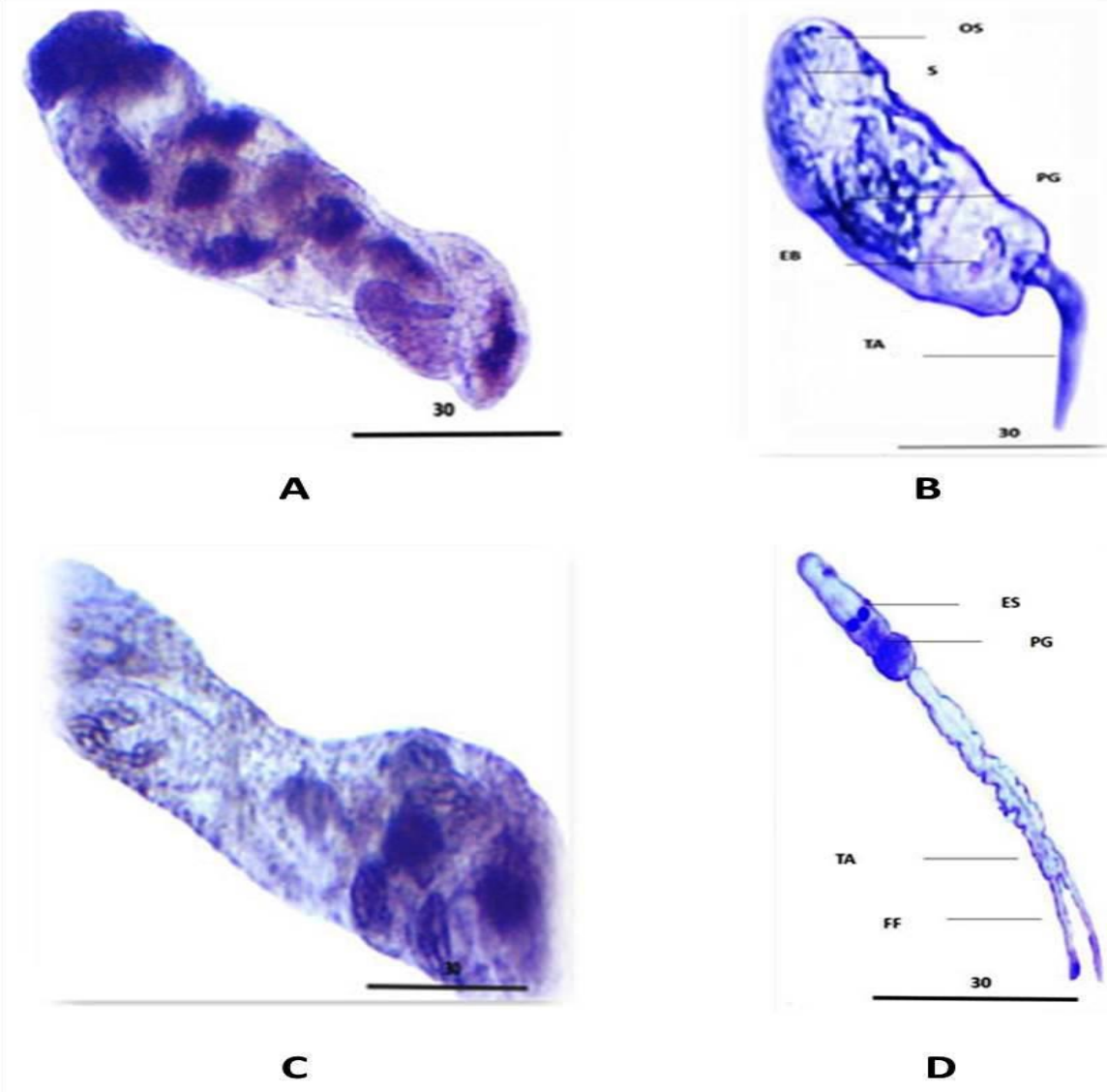

F. 4 